\title{
Bureaucratic Birthdates: Chronometric Old Age as Resource and Liability in U.S. Refugee Resettlement
}

\author{
KIMBERLY SEIBEL
}

\section{Abstract}

This article examines age in refugee resettlement by connecting it to the bureaucratic contexts in which refugees acquire and become categorized by birthdates found in their documents. Frequently used as an objective metric, chronometric age takes on new meaning in migration and determines access to work and welfare. This article traces the trajectory of age documents of refugees in a program for "seniors" (sixty and up) in Chicago, Illinois. Drawing upon anthropology and critical gerontology scholarship, I resituate chronometric age in the dynamic relationship between institutions and definitions of old age in the United States. My purpose is to call attention to the consequences of applying U.S. concepts of age to refugees with limited resources.

\section{Résumé}

Cet article étudie la question de l'âge dans la réinstallation des réfugiés en la reliant aux contextes bureaucratiques à travers lesquels les réfugiés sont identifiés et classifiés selon la date de naissance qui se trouve sur leurs documents. L'âge chronométrique, d'usage fréquent comme mesure objective, acquiert une signification nouvelle dans le contexte de la migration et détermine l'accès à l'emploi et à l'assistance publique. Cet article retrace le parcours des documents portant sur l'âge des clients d'un programme pour "personnes âgées " (6o ans et plus) qui sont réfugiés à Chicago (Illinois). En faisant appel aux recherches en anthropologie ainsi qu'en gérontologie critique, je recontextualise le concept de l'âge chronométrique dans la relation dynamique entre les institutions et les définitions de la vieillesse aux États-Unis. Mon objectif est d'attirer l'attention aux conséquences qui en résultent si les concepts de vieillesse aux États-Unis sont appliqués à des réfugiés disposant de ressources limitées.

\section{Introduction}

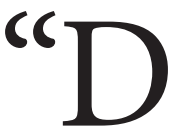
o you know how old you are?" I asked at the very opening of an interview with a couple from Burma/Myanmar. My interpreter translated my questions into Karen as we sat at a small table in the living room of their one-bedroom apartment. Saw Ker Por ${ }^{1}$ received Supplemental Security Income (ssI) because his documents established his age as seventy-two. Naw Nee Ah, who took care of their disabled daughter, was fifty-nine according to her documents and, therefore, not eligible. Looking at them both, I found it hard to believe that she was not the same age as her husband, but neither seemed to care as much as I about their numerical ages.

"My age is sixty," Saw Ker Por said initially, laughing before calling to his wife, "Where has she gone to?"

"I don't know how old you are," Naw Nee Ah answered.

"Sixty," he said, "It is in the papers." In interviews with refugees like Saw Ker Por, I learned that the date in one's documents created a potential gap between refugees' and the U.S. resettlement program's understandings of age.

Carried through airports often in plastic IOM $^{2}$ bags, the documents of newly arrived refugees sometimes contain generic birthdates-1 January for many, 1 July for some Iraqis. Whatever their significance in home countries 
or displacement contexts, these birthdates take on new meanings in the United States. Chronometric age enables U.S. resettlement bureaucracies to process refugees from diverse backgrounds and displacement experiences primarily through mainstream social services. The goal of refugee resettlement is economic self-sufficiency through employment as soon as possible. According to federal policies, refugees eighteen to sixty-four years old are "working age," and sixty-five and older are "non-employable" and "retirement age." 3 The characteristic "work or welfare"4 approach of U.S. resettlement relies upon categorizing refugees by age.

Documents with chronometric age enable newly arrived refugees to apply for mainstream programs like ssi, but this approach creates some problems. Refugees under sixtyfive who did not fit disability standards were expected to work or rely on family members. As "older" workers, they struggled to find and keep appropriate jobs. Case managers had little incentive to help refugees eligible for ssi who still wanted to work. Those who received ssi were vulnerable to losing benefits after seven years unless they were able to pass the citizenship exam. To get around this problem, resettlement programs and refugees sought medical exemptions for this exam with varying success. This tactic reinforced the tendency to limit efforts to integrate refugees deemed nonemployable by age, rather than address underlying issues, such as a lack of English language or other skills or unrecognized education credentials or work histories. These are increasingly issues for current incoming groups 5 and pose a problem to address under current ways of organizing resettlement.

Exploring how bureaucracies provide and process refugees according to birthdates in their documents brings attention to how U.S. constructions of age and aging become transposed onto refugees. I explored the role of age in bureaucratic processes while conducting research at a program serving refugee "seniors" (sixty years and up) in Chicago.

Bureaucratic processes ascribe certain ideas of old age in the U.S. context to refugees. Birthdates provide a means of calculating chronometric age whose significance arises from the assumption that it "will give the most precise and objective information about persons." 6 The term chronomet ric age best describes my observations of the resettlement process as it functioned as "a pseudo-exact labelling device" by which in "a single tick of the clock, one finds oneself in another category."7 In the United States, age is used to assign people status, presenting similarities or differences where there often are none. ${ }^{8}$ I view this approach as a sort of mistranslation that raises the need to examine the cultural ideologies in which chronometric age is embedded.

Anthropology can provide cross-cultural and critical perspectives to make visible the influence of age ideologies in refugee and migration policies. Research has countered the idea of aging as universally chronological. ${ }^{9}$ Collapsing age into chronometric age is a problem, because ultimately "chronometric time is just one, quite limited, way to conceive time" that is "important because of its instrumental and calculative qualities." 10 Categories such as "youth" or "elderly" are also not stable, neutral, or objective but linked to political-economic changes and interactions with the state. ${ }^{11}$ To address such issues, age should be considered as an explicit analytic - on the level of gender, race, and classfor examining power dynamics in migration and globalization processes. ${ }^{12}$

Research on the categorization of refugees is important, because "these attempts to figure out who refugees are reveal a great deal about the categories that Americans use to assign people to their proper place."13 Scholars have linked the "productive citizenship" emphasis in resettlement ${ }^{14}$ with employment as the basis of social citizenship to processes of inequality based on gender, race/ethnicity, and class, "categories and mechanisms that daily produce the norms of differential belonging." 15 Age and aging belong among these considerations. My approach is to trace the actual processes of ascribing age to refugees and the ideas and resources attached to it.

\section{Research Context: The Senior Program}

Midwest Migration Services (MMs) was one of two Senior Programs in all of Illinois after a reduction in the state's Services to Older Refugees discretionary grant in 2012. The goal of these programs was to provide refugees ${ }^{16}$ with case management services to facilitate their access to a shifting cast of targeted and mainstream social services subject to funding changes and cuts. In addition to case managers, the program relied on volunteers, family members, friends, and clients themselves to perform the paperwork and advocacy needed to achieve access to such programs.

From 2013 to $2015^{17}$ I took on an active participantobserver role at the Senior Program at MMS. I accompanied clients to appointments at local Social Security and Illinois Department of Human Services offices, assisted with monthly senior workshops and field trips, and attended relevant meetings. I also interviewed staff members and volunteers at Midwest Migration Services and other local resettlement agencies, community-based organizations, advocacy organizations, and relevant government resettlement and social services agencies.

I conducted life history interviews of refugees enrolled in the Senior Program and reviewed their case files and identification documents. My participants were thirty refugees from twenty-three households: ten (five men, five women) from Iraq, ${ }^{18}$ eleven (five men, six women) from Bhutan, ${ }^{19}$ 
and nine (seven men, two women) from Burma/Myanmar. ${ }^{20}$ These three groups were the largest nationalities in the Senior Program and also accounted for more than half of refugee admissions in recent years. ${ }^{21}$ I hired community members to interpret, transcribe, and translate interviews conducted in the refugees' homes, often with family members present. All of the participants were in their sixties to eighties according to their documents and had been in the country for seven or fewer years. In formal, semi-structured interviews, I asked about their work and education histories, migration trajectories, English language learning, and feelings of in/dependence in the United States. I also asked them to compare ideas of age and later life support systems in their countries of origin with those in the United States.

My research participants would have been difficult to locate outside of a context such as the Senior Program, which faced difficulties reaching out to seniors not resettled by their agency. It is unclear whether refugees not included in the program would have been different from those in my study. Like many refugee programs and researchers, I also relied on interpreters working in many different languages (Karen, Burmese, Assyrian, Arabic, and Nepalese) to reach my non-English-speaking participants. Still I was able to interact with my participants and their family members outside of the program in greater depth. My combination of active participant observation and interviews enabled me to gain access to a diverse group of refugees and their encounters with U.S. resettlement bureaucracy.

\section{Chronometric Markers of Old Age in the United States}

Divorced from the political, economic, and social contexts, chronometric age distinctions in refugee resettlement raise questions about the basis upon which the U.S. government and associated agencies grant assistance to refugees and U.S. citizens. Preconceived categories are a problem in attempts to understand and assist refugees. ${ }^{22}$ Labelling refugees as "youth," often according to Western criteria and norms, can obscure their engagement in political and economic activities. ${ }^{23}$ In terms of aging, the supposed precision of chronometric age "obstructs the acknowledgment of constitutive narratives about aging and reproduces them without any critical reflection." 24 The hidden assumptions of chronometric age are essential to understanding how refugee resettlement programs "read" the birthdates on refugees' documents.

Perspectives from recent critical gerontology scholarship show how understandings of old age take on meaning in relation to the historical and institutional contexts of working and retirement in the United States. Through the development of the welfare state, age became a basis upon which governments managed the productivity of a population as well as identified and addressed social problems arising from the risks of industrial capitalism. ${ }^{25}$ Bismarck first instituted retirement age-seventy years-in Germany in $1889 .{ }^{26}$ Later than European countries, the United States established Social Security in 1935, followed by the Older Americans Act (OAA) in 1965, and these policies greatly reduced the poverty of older Americans. ${ }^{27}$

Over time these retirement policies became the markers of old age itself ${ }^{28}$ and contributed to negative characterizations of the elderly. ${ }^{29}$ The transfer of social welfare from the family to public institutions, ${ }^{30}$ processes that were related to a growing middle class, ${ }^{31}$ helped produce age grades or norms and contributed to the greater uniformity of the life course in segments of U.S. society in the post-Second World War era.

Concepts of old age continue to reflect shifting relationships between individuals and the labour market. The linking of old age to employability can reinforce government practices that use retirement age as a means of managing surplus labour. ${ }^{32}$ In many Western countries, a fixed age of retirement "encouraged the view that, past a certain age, an individual's economic and social worth is diminished." $33 \mathrm{~A}$ cultural legacy of these policies was to transform the social meaning of aging to labour market criteria such as employability and open the doors to the devaluation of older people in the labour market. ${ }^{34}$ The United States has legislated against age discrimination, beginning with the 1967 Age Discrimination in Employment Act (ADEA) and banned mandatory retirement at any age altogether in 1986.35

Chronometric age is an example of governmentality implicating self-knowledge and personal conduct ${ }^{36}$ in its new social and personal meanings.37 Expressions such as "looking good for your age" or "aging badly" express disjuncture between aging and chronometric age but still reinforce the use of age as a guidepost in the United States..$^{38}$ Chronometric age continues to be used as an indicator of health, productivity, vulnerability, and, of course, aging, despite the fact that it is not a determinant of any of these. 39

Chronometric definitions implicate social inequalities, even as they treat old age as genderless and stripped of class and race/ethnicity, rendering forms of privilege, such as retirement, invisible. ${ }^{\circ}$ Race and class inequalities in the labour market contribute to differences in later life resources, such as African Americans having to rely on disability rather than retirement. ${ }^{41}$ Gender-based discrimination, including lifelong income inequality and retirement policies based on the male breadwinner, disadvantage women in later life. ${ }^{42}$

Concepts of old age can enforce normative ideas of aging, despite the fact that the prosperity and consumer lifestyles 
associated with retirement are often limited to a privileged segment of the population. For example, middle-class prosperity and the mass consumer youth culture of the baby boomer generation contributed to "third age," meaning "life after the responsibilities of paid employment and child rearing are over," 43 defined in contrast to "fourth age" or "dependence, decrepitude and death." 44 In the 1990 and 20oos, neo-liberal policies and changes in the labour market have eroded the income pillars of retirement security-welfare, employers, and personal savings. ${ }^{45}$ Lifelong employment is more rare, and employers take less responsibility for the old age of their employees. ${ }^{46}$ Recent "anti-aging" and "successful aging" discourses suggest that that "fourth age" is within one's power to avoid or delay and reinforce aging as a personal responsibility whose risks are to be managed individually rather than collectively. 47

Conducting life history interviews with refugees serves as a reminder that retirement is not a universal life stage but a privilege based on resources. Labelling refugees dependent upon ssi and family members as "retirement age" masks such differences in later life circumstances.

\section{Establishing Age in Refugee Settings}

Retirement can often evoke a fixed age or life stage, but Mr. Karim Hussain had moved in and out of retirement in his lifetime. A divorced musician from Iraq, he was unique among my research participants in having had one lifelong career. When this livelihood put him at risk of violence in Iraq, he moved to Syria, where he spent eight years living on retirement money from Iraq while still practising his profession. After being resettled to the United States, he supported himself with ssi based on age (seventy), which he referred to as his "retirement money."

Sitting in the living room with Mr. Hussain and his son, I talked to the elder about age and retirement in the United States and Iraq, with the help of my interpreter. When I asked him what age he thought people should retire at, he said fifty or fifty-five. When I said that in the United States it was sixty-five, he responded, "Well, I come from Iraq. So I feel that I am retired." I asked him about his birthdate, and he said that he knew his birth year but not the day. He explained that many Iraqis have 1 July birthdates through some process that happened a long time ago for some people in his generation. The date of one's birth was not important. “They forget about it actually," Mr. Hussain said.

Using chronometric age in refugee resettlement presumes that everyone knows his or her birthdate. Given that refugees are by definition people who have fled their countries under fear of persecution, ${ }^{48}$ the dates in their documents can reflect complicated, exclusionary, or absent relationships to bureaucracies.
When refugees do not have these documents, UNHCR and its affiliate NGOs must provide them with one before they can refer cases for resettlement to the United States. Some refugees never knew their birthdates, and they can provide only a year or a best guess. A staff member or translator might make an error during processing, or refugees might purposefully disguise their birthdate during different points in their displacement trajectories. ${ }^{49}$ The de facto generic birthdate provided by UNHCR or affiliates is 1 January. But as in the example of Mr. Hussain, even generic birthdates vary culturally, and registration before and during displacement can affect subsequent processes.

As universal as it might seem at times, documenting age varies with culture as well as a country's resources, politics, and bureaucratic organization. The uN statistics department in its annual Demographic Yearbook raises some of the difficulties involved in documenting age and forming comparisons between countries. These include "differences in the method of reckoning age," such as in the Chinese system, in which "a child is considered one year old at birth and advances an additional year at each Chinese New Year,"5o and "a general tendency to state age in figures ending in certain digits (such as zero, two, five and eight)." ${ }^{11}$ Different traditional calendars ${ }^{52}$ and conversions between them can also create problems.

Having statistics on age, birth, and death in a country requires a functioning government with a good relationship to its people-something that is by definition a problem for a country whose members are violently excluded. As in Bhutan and Burma/Myanmar, governments can exclude by denying or revoking documentation. ${ }^{53}$ In Iraq, conflicts from the 1990 on onward have limited civil registration activities and shaped the birthdates encoded through them. A report by the UN in 2007 noted incompetence as well as deliberate actions by the population:

The system is unreliable-sometimes people intentionally give out inaccurate information to avoid compulsory military services or for certain financial benefits. Administratively, there are not enough registration offices around the country. There is one headquarter office located in Baghdad and 11 suboffices in the city. For the rest of the country, only 1 office exists in each province to cover the registration. The registrars are lack of [sic] qualifications and experiences and most of them are just barely literate. The registration of vital events is not complete, nor does it cover all areas in the country. From the most recent studies on fertility and mortality, the coverage of birth and registration in Iraq is $68 \%$ and $34 \%$, respectively. 54

Whether one is from a rural or urban area, born in a hospital or at home can affect birth registration. UNICEF notes a 
concern that "only half of the children under five years old in the developing world have their births registered." 55 Some Iraqis were never given nor sought out documentation of their births. Even the former dictator of Iraq, Saddam Hussein, did not know his birthdate, which is listed in one official biography as 1 July 1939 . He later established it officially as 28 April 1937 to appear more authentic and to make himself appear older. ${ }^{56}$ The connection between birth and date is not always so clear-cut.

Because refugees often move through different contexts, a birthdate given in one setting for skirting labour laws or conscription into military service could become a problem for accessing government benefits immediately or decades later. Ages cannot be objectively assessed, 57 but bureaucratic processes create a basis for certainty and precision. Many refugee, asylum, and other migration processes hinge on determining age and categorizing people based on it, creating opportunities or disadvantage in different places and life stages.

\section{Entry to the United States: Age Categorization in Refugee Resettlement}

Refugees carry their ages in physical documents into the U.S. system, usually in the form of a passport or travel document and an I-94..$^{58}$ The last is a small white card that documents the entry of non-citizens by the Department of Homeland Security and includes birthdate, first and last name, country of origin, date of arrival, and an $A$ or "alien" number on the back. This number serves as an important identifier in resettlement until refugees can apply for and receive a Social Security number. The stamp on an I-94 indicates that the person is a refugee and authorized to work. Such documents prove that a refugee is an "eligible non-citizen" and can receive public benefits.

Chronometric age is important because of U.S. resettlement policies and the larger structure of the welfare state. To help "older refugees" (sixty and over), the federal Office of Refugee Resettlement (ORR) provides discretionary grants to individual states to help refugees access mainstream OAA and other local aging services. The result is that age becomes a means by which refugees and their families gain income and other resources that can serve as an important element of "self-sufficiency" plans.

Once in the United States, refugees and their family members face short timelines for becoming self-sufficient. Every refugee has a primary case manager, who works with families to establish a self-sufficiency plan, as well as apply for a Social Security card and basic benefits, such as Refugee Cash Assistance (for eight months), Medicaid, the Supplemental Nutrition Assistance Program (or Food Stamps), and Temporary Assistance for Needy Families. At Midwest
Migration Services, primary case managers referred clients to two in-house age-based programs: the Senior Program (refugees sixty and older) to apply for oAA and other benefits, and the Youth Program (refugees under eighteen) to enrol in school, day care, or other activities. Case managers refer "employable" or "working age" refugees to the Employment Program, and if enrolled, the staff and the refugee client are held to assessments based on finding and keeping employment.

At every intake to the Senior Program, staff asked refugees for all of their documents, photocopied them, and then placed them in paper case files to be used to apply for mainstream OAA and other government benefits. These case files as well as the number of clients served and the number of referrals to outside programs were the focus of evaluations of the Senior Program. Caseworkers must refer all refugees who are sixty-five and older to apply for Supplemental Security Income, and they may also help refugees under sixty-five apply on the basis of disability. Applying for ssi on the basis of age is considerably easier. It requires less documentation and takes only a few months, compared to the six months to several years to apply for disability, sometimes with the help of an attorney. Age parameters also define eligibility for other oAA benefits in Illinois: senior subsidized housing (sixty-two or disabled, or fifty-five and over for "Reduced Age" Senior buildings), Free Ride transportation pass (sixty-five and more or disabled), Meals on Wheels (sixty and more), and the Low-Income Home Energy Assistance Program (priority application period for sixty and more or disabled).

OAA benefits helped caseworkers as they negotiated limited timelines and self-sufficiency standards. In Illinois, the Community Care Program (CCP) enables family members (other than spouses) to work as caregivers for their older relatives or friends. Eligibility was based on age (sixty and more) and an in-depth assessment whose translation posed a problem for migrants. 59 Caseworkers at Midwest Migration Services regularly made use of CCP, which, along with ssi, formed part of a strategy of "patchworking"6o a variety of resources for resettlement. Budget issues continue to affect Illinois social services, including $\mathrm{CCP}$, and such resources have grown increasingly scarce under the current governor and his pro-business agenda. ${ }^{61}$

The Senior Program relied on mainstream and targeted programs vulnerable to budget cuts, which affected services clients received. In general, funding for programs for refugees other than employment services was not consistent. For example, a neighbourhood English Language Training program served clients that MMs staff described as "not likely to be employed." It began as a Women's Empowerment Program (that admitted men) until MMs received funding to 
implement a program designed specifically for "older" refugee learners. After this program was cut in 2012, the class remained through the efforts of a volunteer, still teaching some of the same students for the last ten years. Her unpaid work provided consistency in the English-learning efforts of these refugees.

Without programs to support their pathways to citizenship, refugees cannot depend on government benefits as a means of self-sufficiency. Maintaining benefits, like ssi, requires knowledge of English and bureaucratic processes to avoid reduction or cancellation of benefits. Refugees can lose ssi in seven years if they do not receive citizenship, which requires passing a citizenship test. More than half of refugees arriving in the past several years are not literate in their native language and thus face considerable challenges to learning English. ${ }^{62}$ Another option is to have a doctor fill out a medical waiver describing why a refugee is physically or mentally incapable of learning English. To receive approval requires very thorough descriptions, and I learned that doctors were sometimes unwilling to fill out this form, especially for patients whom they hardly knew. In 2008, Congress approved a temporary extension of the time limit to nine years, ${ }^{63}$ a stopgap measure that did little to address the root problems underlying the challenges to gaining citizenship. The extension expired in 2011 affecting an estimated 11,00o people. ${ }^{64}$ In my research, I encountered several refugees beyond the seven-year limit, and the Senior Program helped them apply for Aid to the Aged Blind and Disabled (AABD), a state program that provides an even lower income than SSI. In 2014, Illinois had just over 100 refugee/asylees on AABD.

Refugees face additional problems that mainstream OAA and other programs do not address, such as the loss of traditional status or role reversals. ${ }^{65}$ Refugees arrive with physical and mental health issues linked to displacement, poor nutrition and health care in refugee camps and third countries. They are often more isolated in the United States than they were in their home countries. ${ }^{66}$ Resettlement and the experience of undergoing aging in the United States can be a source of stress for refugees. ${ }^{67}$ Clearly policies for mainstream Americans are not set up to address these issues.

\section{Non-Employable by Age}

Despite the resources available to refugees, the use of chronometric age reinforces an uncritical treatment of older persons in the United States as unproductive. Case managers apply for ssi for all refugees over sixty-five, regardless of their ambitions to work. Researchers of U.S. refugee resettlement have noted the strategic use of the "non-employable" category in resettlement agencies as a way to manage limited resources and performance outcomes. ${ }^{68}$ Over twenty-five years ago, Gozdziak reported this problem for older refugees in the United States: "Since it is easier to reach performance goals when working with younger, better educated clients, the agencies may be reluctant to serve more difficult clients." 69 It reflects the idea that in resettlement, "any 'difficult' new case, whether because of age, health, education, or socioeconomic background, is a potential threat to the success of the resettlement program."70 Making use of a non-working, "retirement" role is certainly easier.

Resettlement staff often pointed to the fifty-to-sixty-four age group as the most difficult to help. Staff at Midwest Migration Services told me that refugees in their sixties who sought assistance in finding employment were rare. Members of the Employment team talked about holding easier positions, such as cleaning up at a local theatre, for people who would otherwise have trouble finding work. I learned from my interviews with refugees that sometimes caseworkers told them that they could not work. For example, Dhanraj Thapa, a man from Bhutan, told me, "I was expecting to work, but my caseworker ... said to me that I would not be able to work." Entering the labour market can be difficult, even for Americans perceived as "older."71 Refugees who wanted to or had to work faced challenges, from getting hired, to the physical demands of a job that was inflexible to fluctuations in health.

The sharp distinction between working and retirement was also new for refugees from rural backgrounds that would have transitioned to easier tasks before stopping work, if at all. Not having a job can make it difficult for refugees to feel integrated..$^{2}$ The standard of sixty-five years as "retirement age" was higher than Mr. Hussain and some others expected. Many of my participants felt that better health care and other conditions made aging happen more slowly in the United States than it had for them. Still others expected to work their whole lives. As a form of later life support, getting ssi was more reliable than relying on family members, but it also limited my refugee participants' overall integration.

\section{Generic Age in the Social Security System: What Does "Aged" Mean?}

Getting a Social Security Card was an important initial step in resettlement and an entry point into an enormous government program and bureaucracy that currently provides benefits for 61 million Americans. ${ }^{73}$ These include retired and disabled workers, their dependents, and survivors. ${ }^{74} \mathrm{~A}$ generic redbrick building with small, square windows and glass front doors was the preferred local office for Midwest Migration Services. It housed two programs: employmentbased Social Security, and means-tested ssi. Both programs employ chronometric age distinctions, but only people with 
a recognized employment history have access to Social Security. The ssi program defines "aged" as precisely sixtyfive years and older.75

On an early January morning, I accompanied a Congolese man to apply for ssi. He had just turned sixty-five, according to his documents. He, an interpreter from Midwest Migration Services, and I were seated on grey metal chairs clustered around the desk of a Social Security caseworker. As we passed over the documents for him and his family members, I noticed that his entire family had 1 January birthdays. When I asked him about it, with the help of the interpreter, he explained that he had told the interpreter at the refugee camp his birthdate, but the UNHCR representative wrote $1 / 1$ anyway. Despite this discrepancy, his documents had now indicated his status as eligible for ssI, a moment that Midwest Migration Services had been eagerly anticipating. With ssi, the family would no longer need rent assistance, but they could only schedule an appointment to apply after his bureaucratic birthdate.

Social Security is a form of social insurance. Workers in the United States earn points towards their retirement, and they need at least ten years of work in the United States (or in countries with agreements with the United States) to qualify for these benefits. Supplemental Security Income is a means-tested program funded through general government revenue. Established under the Nixon administration, ssi federalized state programs for people who are blind, disabled, or "aged," and have limited income or assets. Since 1974, ssi has provided income at three-quarters of the poverty level: currently $\$ 733$ for an individual and $\$ 1100$ for a married couple. Rates of accessing SsI are lower than those for Social Security, as "means-tested programs such as ssi have generally had difficulty in achieving high rates of participation among those eligible."76 Programs like ssi are always made through "a claim based on a socially produced understanding of what is fair treatment."77 Managing program constraints, resettlement caseworkers use refugees' ages to access ssi, reinforcing an arbitrary definition of "aged" applied to refugee newcomers. Without recognized work histories, refugees have no access to Social Security, and as a result, their future incomes and conditions of aging are pinned to their families or this federal program.

\section{Conclusion}

U.S. resettlement programs use chronometric age to integrate and assign status to newly arrived refugees with a self-sufficiency focus that clearly implicates age. The "work or welfare" paradigm in U.S. resettlement supports the narrow scope of the program, and age categorization obscures a host of challenges to integration. The refugees I studied struggled to find meaningful roles and to learn English in order to get citizenship and maintain benefits that supported them and their families. Chronometric age was the basis for securing access to mainstream OAA and other services, but the age guidelines created an arbitrary division between refugees worthy of assistance and those who were not. Such guidelines create problems for refugees who rely on family or finding appropriate work as a newcomer and "older" worker.

Chronometric ages can appear neutral but are inherently linked to the moral and political economy of the welfare state. Governments have used the institutional life course and chronometric age parameters to manage the risks and relationships to the market, and one result is that concepts of age, including chronometric age, are laden with normative ideas. By assigning characteristics to individuals, ideas of age can obscure hidden forms of privilege and inequality in later life, such as retirement. Refugees lack the place-based work histories that form the basis of Social Security claims, but they are still considered "retirement age" if they receive a meagre income through ssI. U.S. resettlement and associated programs gloss over these issues when they use refugees' bureaucratic birthdates as the basis of categorization and assistance.

This article has focused primarily on "older" refugees, but its findings highlight the need for critical analysis of the underlying assumptions and ideological framings of age and aging in refugee policies and practices and what these patterns indicate about structural inequalities in the United States. Examining the bureaucratic basis of ages in refugees' documents is the approach I have taken. Birthdates and chronometric ages make refugees "legible"78 to different bureaucracies. This process, however, assumes that refugees have an age, divorced from context that is true and consistent as they move through different migration contexts. Refugees are in flux, crafting new identities, and adapting to new social and economic conditions; therefore, a more useful approach is to consider how concepts of age might limit or enable refugees in accessing rights and resources for meaningful integration.

\section{Notes}

1 Following standard ethnographic practices, I have given a pseudonym to the research organization and all of my research participants.

2 The International Organization of Migration (IOM) is responsible for coordinating all travel for resettled refugees.

3 Refugees are also exempt from employment if they are pregnant, disabled, or a primary caretaker of someone at home, such as a child under the age of one. At sixteen, refugees are technically able to work but are usually in school. Office of Refugee Settlement, "Report to the Congress: Proposed Refugee Admissions for Fiscal Year 2016” 
(Washington, DC: U.S. Department of Health and Human Services, October 1, 2015), http://www.state.gov/documents/organization/247982.pdf.

4 Mansha Mirza, "Occupational Upheaval during Resettlement and Migration: Findings of Global Ethnography with Refugees with Disabilities," Occupational Therapy Journal of Research: Occupation, Participation, Health 32, no. S1 (2012): S7-S14.

5 Randy Capps, Kathleen Newland, Susan Fratzke, Susanna Groves, Michael Fix, Margie McHugh, and Gregory Auclair, "The Integration Outcomes of U.S. Refugees: Successes and Challenges," Migration Policy Institute, June 2015, http://www.migrationpolicy.org/research/integration-outcomes-us-refugees-successes-and-challenges.

6 Jan Baars, Aging and the Art of Living (Baltimore, MD: Johns Hopkins University Press, 2012), 8.

7 Ibid., 32.

8 Chris Phillipson, Ageing, Key Concepts Series (Cambridge: Polity, 2013), 57; Baars, Aging and the Art of Living, 53.

9 Caroline H. Bledsoe, Contingent Lives: Fertility, Time, and Aging in West Africa, Lewis Henry Morgan Lectures 1999 (Chicago: University of Chicago Press, 2002); Susan J. Rasmussen, The Poetics and Politics of Tuareg Aging Life Course and Personal Destiny in Niger (DeKalb: Northern Illinois University Press, 1997); Margaret M. Lock, Encounters with Aging: Mythologies of Menopause in Japan and North America (Berkeley: University of California Press, 1993); David I. Kertzer and Jennie Keith, eds., Age and Anthropological Theory, Cornell Paperbacks (Ithaca, NY: Cornell University Press, 1984).

10 Baars, Aging and the Art of Living, 7.

11 Sue Ruddick, "The Politics of Aging: Globalization and the Restructuring of Youth and Childhood.," Antipode 35, no. 2 (1 March 2003): 334-62; Julia Meredith Hess and Dianna Shandy, "Kids at the Crossroads: Global Childhood and the State," Anthropological Quarterly 81, no. 4 (2008): 765-76, doi:10.1353/anq.0.0035.

12 Jennifer Cole and Deborah Lynn Durham, eds., Generations and Globalization: Youth, Age, and Family in the New World Economy, Tracking Globalization (Bloomington: Indiana University Press, 2007); Ruddick, "Politics of Aging"; Sarah Lamb, "Aging across Worlds : Modern Seniors in an Indian Diaspora," in Generations and Globalization: Youth, Age, and Family in the New World Economy, ed. Jennifer Cole and Deborah Lynn Durham, Tracking Globalization, 13263 (Bloomington: Indiana University Press, 2007).

13 David Haines, Safe Haven?: A History of Refugees in America (Sterling, va: Kumarian, 2010), 14.

14 Dianna J. Shandy, Nuer-American Passages: Globalizing Sudanese Migration, New World Diasporas (Gainsville: University Press of Florida, 2007).

15 Aihwa Ong, Buddha Is Hiding: Refugees, Citizenship, the New America, California Series in Public Anthropology 5 (Berkeley: University of California Press, 2003), 145.
16 Although I use the term refugee here, the Senior Program served asylees, Special Immigrant Visa (sIv) holders, and Cuban/Haitian entrants. My interview participants were all refugees resettled to the United States, except for one from Iraq who came via an siv.

17 IRB Study \#STUOoog2039 approved 10 April 2014.

18 This group included Arabic and Assyrian speakers, Christian and Muslim participants. Two participants were originally born in Syria but lived in Iraq with Iraqi-born spouses.

19 Most of these participants were Lhotshampa from Bhutan, but one woman was born in India.

20 This group was composed of mostly Karen and a smaller number of Rohingya and Mon participants.

21 In 2013, refugees from Iraq, Burma/Myanmar, and Bhutan accounted for 64.3 per cent of refugee admissions $(69,909$ total) and 61.3 per cent of the 69,975 total in 2014. In Illinois, they accounted for 78.4 per cent of the 2,578 total in 2014. Daniel C. Martin and James E. Yankay, "Refugees and Asylees: 2013," Annual Flow Report (Washington, DC: DHS Office of Immigration Statistics, August 2014), http://www.dhs.gov/sites/default/files/publications/ ois_rfa_fr_2013.pdf; Nadwa Mossaad, "Refugees and Asylees: 2014," Annual Flow Report (Washington, DC: DHS Office of Immigration Statistics, 2016), https://www.dhs .gov/sites/default/files/publications/Refugees $\% 20 \% 26 \% 20$ Asylees\%2oFlow\%2oReport\%202014_508.pdf; Office of Refugee Settlement, "Fiscal Year 2014 Refugee Arrivals."

22 Haines, Safe Haven?, 19.

23 Christina R. Clark-Kazak, Recounting Migration: Political Narratives of Congolese Young People in Uganda (Montreal and Kingston: McGill-Queen's University Press, 2011), 8.

24 Baars, Aging and the Art of Living, 7.

25 Ibid.; Phillipson, Ageing.

26 Axel von Herbay, "Otto Von Bismarck Is Not the Origin of Old Age at 65," Gerontologist 54, no. 1 (1 February 2014): 5, doi:10.1093/geront/gnt111.

27 Andrea Louise Campbell, How Policies Make Citizens: Senior Political Activism and the American Welfare State, Princeton Studies in American Politics (Princeton, NJ: Princeton University Press, 2003), 18-21.

28 John A. Vincent, Chris Phillipson, and Murna Downs, eds., The Futures of Old Age (London: Sage Publications, 2006).

29 Jill S. Quadagno, The Transformation of Old Age Security: Class and Politics in the American Welfare State (Chicago: University of Chicago Press, 1988); Thomas R. Cole, The Journey of Life: A Cultural History of Aging in America, Canto edition (Cambridge: Cambridge University Press, 1997).

30 Tamara K. Hareven, "Aging and Generational Relations: A Historical and Life Course Perspective," Annual Review of Sociology 20 (1 January 1994): 437-61, doi:10.2307/2083373; Howard P. Chudacoff, How Old Are You?: Age Consciousness in American Culture (Princeton, NJ: Princeton University Press, 1989). 
31 Ruddick, "Politics of Aging," 335; Chris Gilleard and Paul Higgs, Contexts of Ageing: Class, Cohort and Community (Cambridge: Polity, 2005); Gilleard and Higgs, Cultures of Ageing: Self, Citizen, and the Body (Harlow, uk: Prentice Hall, 200o).

32 Phillipson, Ageing, 63.

33 Alan Walker, "Reexamining the Political Economy of Aging: Understanding the Structure/Agency Tension," in Aging, Globalization and Inequality: The New Critical Gerontology, ed. Jan Baars, Dale Dannefer, Chris Phillipson, and Alan Walker (Amityville, NY: Baywood Publishing, 2006), 62.

34 Quadagno, Transformation of Old Age Security, 6.

35 David Neumark, "Age Discrimination Legislation in the United States," Contemporary Economic Policy 21, no. 3 (July 2003): 297.

36 Michel Foucault, 2003): 297.ation in thThe Foucault Effect: Studies in Governmentality, ed. Graham Burchell, Colin Gordon, and Peter Miller, 87-105 (Chicago: University of Chicago Press, 1991).

37 Chudacoff, How Old Are You?

38 Ibid.

39 Kirkwood 1999 cited in Baars, Aging and the Art of Living, 15.

40 Margaret Cruikshank, Learning to Be Old: Gender, Culture, and Aging (Lanham, MD: Rowman \& Littlefield Publishers, 2003).

41 Rose C. Gibson, “The Black American Retirement Experience," in Aging for the Twenty-First Century: Readings in Social Gerontology, ed. Jill S. Quadagno and Debra Street, 309-26 (New York: St. Martin's, 1995).

42 Meredith Minkler and Carroll L. Estes, Critical Perspectives on Aging: The Political and Moral Economy of Growing Old (Amityville, NY: Baywood Publishing, 1991), 23-4; Cruikshank, Learning to Be Old.

43 Gilleard, Contexts of Ageing, 1.

44 Ibid., 39; Peter Laslett, A Fresh Map of Life: The Emergence of the Third Age (Cambridge, MA: Harvard University Press, 1991).

45 Phillipson, Ageing; Larry Polivka, "Neoliberalism and Postmodern Cultures of Aging," Journal of Applied Gerontology 30, no. 2 (1 April 2011): 173-84, doi:10.1177/0733464810385919; Larry Polivka, “The Growing Neoliberal Threat to the Economic Security of Workers and Retirees," Gerontologist, no. 1 (2012): 133-43.

46 Phillipson, Ageing, 101; Christine L. Fry, "Globalization and the Risks of Aging," in The Cultural Context of Aging : Worldwide Perspectives, ed. Jay Sokolovsky, 2nd ed., 185-95 (Westport, ст: Bergin \& Garvey, 1997).

47 Cole, Journey of Life; Polivka, "Neoliberalism and Postmodern Cultures of Aging."

48 According to the 1951 Convention, a refugee is "someone who is unable or unwilling to return to their country of origin owing to a well-founded fear of being persecuted for reasons of race, religion, nationality, membership of a particular social group, or political opinion.” UNHCR, "Convention and Protocol Relating to the Status of Refugees” (Geneva: UNHCR, December 2010), 3, http://www .unhcr.org/3b66c2aa1o.html.

49 Mariane C. Ferme, "Deterritorialized Citizenship and the Resonances of the Sierra Leonean State," in Anthropology in the Margins of the State (Santa Fe, NM: Oxford: School of American Research Press, 2004), 1:103-4.

50 UN, United Nations Demographic Yearbook 2013 (New York: United Nations, Department of Economic and Social Affairs, 2013), 14n7, http://unstats.un.org/unsd/ demographic/products/dyb/dybsets/2013.pdf.

51 Ibid., 5 .

52 For example, Karen people do not use the same calendar as the majority Burman group of Burma/Myanmar.

53 U. Shwe Maung, "Myanmar's Disenfranchised Rohingya," New York Times, 2 November 2015, http://www.nytimes .com/2015/11/o3/opinion/myanmar-election-disenfranchised-rohingya.html; Michael Hutt, "The Bhutanese Refugees: Between Verification, Repatriation and Royal Realpolitik, Peace and Democracy in South Asia 1, no. 1 (January 2005).

54 United Nations Statistics Division, "Report on the United Nations Workshop on Civil Registration and Vital Statistics for escwa Region," Central Agency for Public Mobilization and Statistics of Egypt, December 2007, 18, http:// unstats.un.org/unsd/demographic/meetings/wshops/ Civil_Registration_Deco7_Cairo/docs/Final\%2oreport\% 2oworkshop\%2oEscwA.pdf.

55 Terry Smith and Laura Brownlees, "Age Assessment Practices: A Literature Review \& Annotated Bibliography" (New York: UNICEF, April 2011), 1, http://www.unicef.org/ protection/Age_Assessment_Practices_2010.pdf.

56 Coughlin explained, "At this time it was the custom for authorities to give all peasant children the nominal birth date of July 1; it was only the year that they attempted to get right. This would explain why a certificate presented in one of Saddam's official biographies gives July 1, 1939, as the date of his birth." According a private source, "Saddam was always jealous of Karim for knowing his own birthday. So Saddam simply copied it for himself." Con Coughlin, Saddam: The Secret Life (London: Macmillan, 2002), 2-3.

57 Smith and Brownlees, "Age Assessment Practices."

58 As of September 2015, U.S. Customs and Border Patrol has transitioned to an automated I-94.

59 Madelyn Iris, "Aging and Transnational Immigration," in Applying Anthropology in the Global Village, ed. Christina Wasson, Mary Odell Butler, and Jacqueline CopelandCarson (Walnut Creek, CA: Left Coast, 2012), 185.

60 Nazli Kibria, "Household Structure and Family Ideologies: The Dynamics of Immigrant Economic Adaptation among Vietnamese Refugees," Social Problems 41, no. 1 (February 1994): 81-96.

61 Kim Geiger, "Rauner Says He’ll Use 'Leverage' of Money Woes to Get Pro-Business Changes," Chicago Tribune, 
6 April 2015, http://www.chicagotribune.com/news/ local/politics/ct-bruce-rauner-statewide-tour-met0407-20150406-story.html.

62 Capps et al., "Integration Outcomes of U.S. Refugees."

63 "SI 00502.301 Supplemental Security Income (SsI) Extension for Elderly and Disabled Refugees Act," Social Security Program Operations Manual System, 2013, https:// secure.ssa.gov/poms.nsf/lnx/0500502301.

64 Kathy Ruffing, "Thousands of Poor Refugees Face Loss of ssi Benefits," Center on Budget and Policy Priorities, Washington, DC, 15 September 2010, http://www.cbpp.org/ sites/default/files/atoms/files/9-15-10pov.pdf.

65 Jeff Chenoweth and Laura Burdick, "The Path to Integration: Meeting the Special Needs of Refugee Elders in Resettlement," Refuge 20, no. 1 (2001): 20; Haines, Safe Haven?, 118; Iris, "Aging and Transnational Immigration."

66 Haines, Safe Haven?, 118.

67 Nicole Dubus, “I feel like her daughter not her mother': Ethnographic Trans-Cultural Perspective of the Experiences of Aging for a Group of Southeast Asian Refugees in the United States," Journal of Aging Studies 24, no. 3 (August 2010): 209, doi:10.1016/j.jaging.2010.02.002.

68 Jessica Darrow, "The Politics and Implementation of us Refugee Resettlement Policy: A Street-Level Analysis" (PhD diss., University of Chicago, 2015); Mirza, "Occupational Upheaval during Resettlement and Migration ."

69 Elzbieta M. Gozdziak, "Older Refugees in the United States: From Dignity to Despair," A Study by Refugee Policy Group, Refugee Studies Centre, Oxford University, 4 January 1988, Forced Migration Online Digital Library, http://repository.forcedmigration.org/show_metadata. jsp?pid=fmo:427.

70 Haines, Safe Haven?, 142.
71 U.S. Senate Special Committee on Aging, "Missed by the Recovery: Solving the Long-Term Unemployment Crisis for Older Workers," 15 May 2012, 112-541. http://www.gpo. gov/fdsys/pkg/CHRG-112shrg75751/pdf/CHRG-112shrg75751. pdf; Randall W. Eberts and Richard Hobbie, eds., Older and Out of Work: Jobs and Social Insurance for a Changing Economy (Kalamazoo, MI: W.E. Upjohn Institute for Employment Research, 2008).

72 Sveta Roberman, "All That Is Just Ersatz: The Meaning of Work in the Life of Immigrant Newcomers," Ethos 41, no. 1 (2013): 1-23, doi:10.1111/etho.1200o.

73 Social Security Administration, "Fact Sheet: Social Security," Social Security, 2016, https://www.ssa.gov/news/press/ factsheets/basicfact-alt.pdf.

74 Ibid.

75 Social Security Administration, "Understanding Supplemental Security Income SSI Eligibility Requirements: 2016 Edition," http://www.ssa.gov/ssi/text-eligibility-ussi.htm.

76 Center on Budget and Policy Priorities, "Introduction to the Supplemental Security Income (ssi) Program," 27 February 2014, http://www.cbpp.org/cms/?fa=view\&id=3367.

77 Melissa Hardy, "Vulnerability in Old Age: The Issue of Dependency in American Society," in Quadagno and Street, Aging for the Twenty-First Century, 174.

78 James C. Scott, Seeing like a State: How Certain Schemes to Improve the Human Condition Have Failed, Yale Agrarian Studies (New Haven, Ст: Yale University Press, 1998).

Kimberly Seibel is a postdoctoral researcher at Wayne State University. The author may be contacted at kaseibel@gmail .com. 